\title{
National Specifics of Language Expression of Macro-concept 'Destiny' in the Arabic Linguoculture: Results of Association Experiment
}

\author{
Manizha Davlatmirova * \\ Faculty of Philology, Russian-Tajik Slavonic University, 30 M. Tursunzoda St., Dushanbe, 734025, Tajikistan
}

\begin{abstract}
The paper describes the culture-bound concept of قدر destiny identified through the association experiment. It suggests linguo-cognitive analysis of reactions obtained during the experiment with native Arabic speakers. The study demonstrates words, lexemes and expressions, which reflect the concept of destiny in the Arabic linguoculture. It also presents phrases and sentences obtained during questionnaire survey, which show the national specifics of this concept. The work provides classification of associations and analyzes the obtained results. All associations, including single ones, were considered in the experiment. The novelty of this work includes the description and identification of cognitive features, semantic pattern of key national elements of a macroconcept قدر destiny in associative consciousness of native Arabic speakers, which represents a component of the Arabic linguoculture.
\end{abstract}

\section{Introduction}

The destiny is the most real and objective concept and category of life directly linked to span of a person and the nation. The everyday human life includes positive and negative connotations of this concept. According to Losev A.F., "The destiny is a rigid image of life", "the harshest clamps pressing our life " $[1,148]$. The destiny refers to the most ancient key concepts of all cultures, and despite social and linguistic development the human worldview always remains in the consciousness of a person, and the representative words of this concept exist in all linguocultures.

\subsection{Literature Review}

According to Lyapin's definition, the concept is a semantic quanta of human life in the world ... Cultural concepts represent specific cultural genes included into the genotype of a culture $[2,16]$. An important aspect of studying a concept is to identify its national and specific features. This is reflected in the research work devoted to the study of macroconcept 'destiny' in the Tajik and Arabic linguocultures. In this regard, to determine the national specifics of a macroconcept destiny in the Tajik, Arabic and Pamir languages, the authors conducted a free association experiment among native speakers. Partially the results of the study upon completion of a free association experiment were analyzed in articles "Monitoring of Tolerance Associative Field and Forecasting of Inter-Ethnical Interrelations Problems: Questionnaire Survey in the University Environment of Tajikistan" [3, 35]; "Reflection of national significant elements of a macroconcept destiny in the Tajik and Pamir linguocultures: questionnaire survey in the * Corresponding author: davlatmirova.manizha@mail.ru university environment of Tajikistan" $[4,78]$ and in the monograph "Study of Tolerance in the Youth Environment of Tajikistan (Linguistic Aspects)" (5, 5674). Any mental formation of another culture is considered ethnographic: according to I.E. Anichkov [6]. It is worth noting the idea of linguistic continuum (V.M. Savitsky), according to which it is possible to identify the degree of idiomatic linguistic unit and mutatis mutandis concerning any linguocultural specifics of a concept [7].

\subsection{Methodological Framework}

Cognitive linguistics applies different methods of study. One of them is the method of free association. The method of free association experiment consists in presenting stimulus words to participants of the experiment, to which they react using any verbal reaction they come across $[8,115]$.

To define the national specifics of a macroconcept destiny in the Arabic linguoculture and to identify the main units representing this concept in Arabic the study covered the free association experiment conducted to obtain authentic reactions of native speakers.

The free association experiment is used to get a comprehensive interpretation of the concept. The free association experiment was conducted among representatives of Arabic population from various Arab countries in order to determine national and specific features, identify relevant features and study the knowledge, understanding and perception of the concept destiny by native speakers at the present stage of the Arabic language development. 


\section{Results and Discussion}

The experiment covered 100 respondents, including 65 men and 35 women. The native language of respondents is Arabic. To receive all possible lexemes, expressions and conceptual features of the studied concept, people of different age groups (from 18 to 45) and different social status (students, teachers, pilots, flight attendants, representatives of airport customs control, businessmen) were engaged into the experiment, including students from Saudi Arabia who study at Tajik National University (Dushanbe, Tajikistan), students of RUDN (Peoples' Friendship University of Russia, Moscow), Oman State University (Muscat), and employees of Hamad International Airport (Qatar).

The respondents were offered to react with any verbal sign to representative words of a macroconcept

قدر in the Arabic. The following stimulus words were suggested: مصير [masir], قضاء و قدر [qaza wa qadar], قسمة [qismat]. Several lexical units expressing the concept of destiny in the Arabic language were presented to reveal all qualities, connotations, both positive and negative. The respondents had to react to these stimulus words without thinking and using the first word, phrase or expression coming to their mind.

The questionnaire showed the following results with respect to stimulus words مصير [masir], قضاء و قدر [qaza wa qadar], قسمة [qismat], present in different regions of the Arab world, as well as in Moscow and Dushanbe.

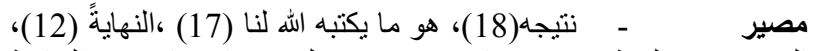

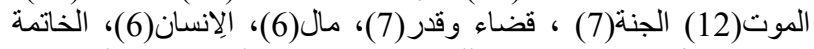

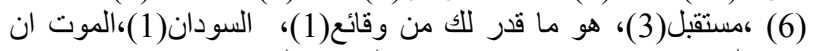

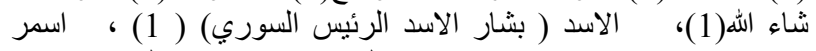

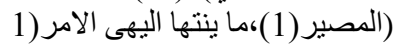

The stimulus word masir-natijatun (result) (19), huwa ma yaktubaha Allahu lana (something ordered by Allah) (17) an-nihayat (end) (11), al-mavt (death, demise) (12), al-janat (paradise) (7), qada wa qadar (destiny and predestination) (7), mal (property) (6), alinsan (person) (6), al-xatimatu (end) (6), mustaqbal (future) (3), huwa ma qadara laka min waqa'yi (something that is predestined in reality) (1), as-Sudan (as-Sudan) (1), al-mawta insha Allah (death, let it be the Allah will) (1), al-Asad (Bashar al-Asad ar-rais asSuriya) (Al-Asad (Bashar al-Asad - president of Syria) (1), asmaru-al-masir (dark destiny) (1), ma yantaha ilayha al-amri (something that comes to an end by order) (1).

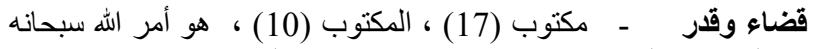

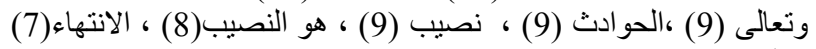

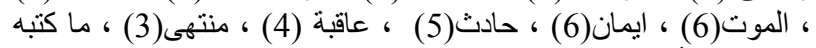

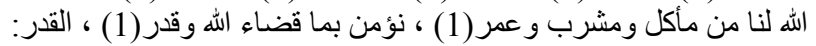

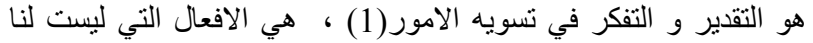

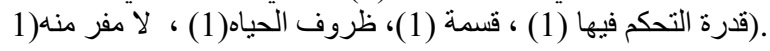

Qada wa qadar - maktub (written, ordered, predestined) (17), al-maktub (written, ordered) (10), huwa amru Allahu Subhanahu wa ta'ala (order of Allah) (9), al-hawadic (event, case) (9), nasib (1. Share, part 2.
Fate, destiny) (9), huwa an-nasib (destiny) (8), al-intiha'i (end, termination) (7), al-mawt (death) (6), iman (faith in God) (6), hadic (accident, incident) (5), 'aqibatun (outcome, consequence, result) (4), muntaha (end) (3), ma kataba Allahu lana min ma'kulu wa mashrub wa 'umr (something that the God ordered us to eat, drink and live (life)) (1), nu'minu bima qada'a Allahu wa qadar (we believe in what the Allah prescribed) (1), alqadar huwa at-taqdir wa at-tafakur fi taswiyati al-umur (assessment and solution of problems (affairs)) (1), hiya af'al al-lati laysat lana qudratu at-tahakama fiha (actions we cannot control) (1), qismatun (destiny, fate) (1), zuruf ul-hayat (living conditions) (1), la mufar minhu (Inevitable!) (1).

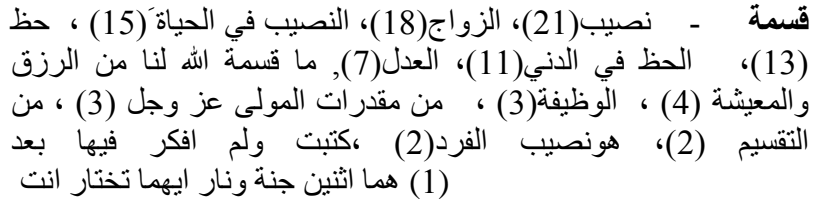

Qismat-nasib (1. Share, part 2. Fate, destiny) (21), az-zawaj (marriage, wedding, matrimony) (18), annasibu fi-al-hayati (life fate) (15), ha dd un (fate, destiny, happiness) (13), alha dd u fi ad-dunyayi (fate, happiness in life) (11), Al-adl (truth, justice) (7), ma qismatu Allahu lana min ar-rizqi wa al-ma'ishati (fate and livelihood which Allah gave us) (4) al-wazifatu (position, post) (3), min muqaddirat al-mawla 'aza wa jalla (something that is predetermined by the Lord) (3), min al-taqsim (upon distribution) (2), huwa nasibu alfardi (fate, destiny of each person) (2), katabtu wa lam afkaru fiha ba'da huma ucnayni, jannatun wa narun, ayuhuma taxtarat (I have written, but I don't think that there are concepts of paradise and hell (fire) and that there will be a choice) (1).

The processing of the free association experiment results allows interpreting the obtained associations as the reflections of some conceptual features of the studied concept $[8,115]$.

As a result of the analysis of obtained reactions and according to experimental data, the following aspects of a macroconcept destiny in the Arabic linguoculture were identified:

\subsection{Linguistic aspect}

The obtained reactions, word nouns articulating the concept destiny within the understanding of Arabic native speakers make it possible to identify differential features of this concept revealed through comparison of lexemes belonging to one synonymic row.

A) The first includes reactions-word nouns: natijatun (result), an-nihayat (end), al-mavt (death, demise), aljanat (paradise), mal (property), al-insan (person), alxatimatu (end), mustaqbal (future), as-Sudan (as-Sudan), al-Asad (Bashar al-Asad ar-rais as-Suriya) (Al-Asad (Bashar Al-Asad - president of Syria), maktub (written, ordered, intended by destiny), al-maktub (written, ordered) al-hawadic (event, case), nasib (1. Share, part 2. Fate, destiny), al-intiha'i (end, termination), al-mawt (death), iman (faith in God), hadic (accident, incident), 'aqibatun (outcome, consequence, result), muntaha 
(end), qismatun (destiny, a share to consider), nasib (1. Share, part 2. Fate, destiny), az-zawaj (marriage, wedding, matrimony), ha dd un (fate, destiny, happiness) Al-adl (truth, justice), al-wazifatu (position, post).

The analysis of synonyms of a keyword articulating the studied concept made it possible to identify the differential features of this concept revealed through comparison of lexemes belonging to one synonymic row $[7,125]$.

B) The second includes reactions-phrases: qada wa qadar (destiny and predestination); huwa ma qadara laka min waqa'yi (something that is predestined in reality); al-mawta insha Allah (death, let it be the Allah will); asmaru-al-masir (dark destiny); ma yantaha ilayha alamri (something that comes to an end by order); huwa amru Allahu Subhanahu wa ta'ala (order of Allah); huwa an-nasib (this is destiny); an-nasibu fi-al-hayati (fate in life); zuruf ul-hayat (living conditions); la mufar minhu (Inevitably!); an-nasibu fi-al-hayati (life fate); alha dd u fi ad-dunyayi (fate, life happiness); min muqaddirat almawla 'aza wa jalla (something that is predetermined by the Lord); min al-taqsim (upon distribution); huwa nasibu al-fardi (fate, destiny of each person).

C) The third includes reactions-sentences: huwa ma yaktubaha Allahu lana (something ordered by Allah); ma kataba Allahu lana min ma'kulu wa mashrub wa 'umr (something that the God ordered us to eat, drink and live (life)); nu'minu bima qada'a Allahu wa qadar (we believe in what the Allah prescribed); al-qadar huwa attaqdir wa at-tafakur fi taswiyati al-umur (assessment and solution of problems (affairs)); hiya af'al al-lati laysat lana qudratu at-tahakama fiha (actions we cannot control); ma qismatu Allahu lana min ar-rizqi wa alma'ishati (fate and livelihood which Allah gave us); katabtu wa lam afkaru fiha ba'da huma ucnayni; jannatun wa narun ayuhuma taxtarat (I have written, but I don't think that there are concepts of paradise and hell (fire) and that there will be a choice).

The received association responses to stimulus words مصير [masir], قضاء و قدر [qaza wa qadar], قسمة [qismat] from the linguistic point of view show that a single word, a phrase and a sentence are the most widespread types of reactions.

The experiment studies the degree of activity or intensity of a concept within individual, group, national and cultural consciousness. If the respondents cannot clearly define the meaning of a word expressing a certain concept, they do not perceive the corresponding concept as intensive $[9,66]$. This technique is disclosed in detail in works of famous linguists [Sternin 2001; Grishchuk 2002; Rudakova 2002, etc.].

Processing and analysis of respondents' reactions made it clear that the concept of destiny for Arabic linguoculture is considered ethnographic.

With regard to associations the recipients express behavioral reactions, objects, processes, phenomena, and values contributing to their routine life, which demonstrate ethnopsychocognitive features of the macroconcept of destiny in Arabic linguoculture. The destiny is a concept, which is directly linked to religion and philosophy thus leading to the next aspect.

\subsection{Religious and philosophical aspect}

Religious and axiological dominant ideas encompassing spiritual value of the given linguoculture are widely utilized in the ordinary consciousness of the Arabs. The analysis of questionnaires showed that the majority of reactions are bound to religion and philosophy since the religion forms an integral part of the nation and is clearly reflected in its language (172).

It should be noted that the destiny within theological aspect is, first of all, bound to Islam since many respondents indicated expressions and aphorisms referring to certain ayahs of the Holy Quran. The reactions related to religion and philosophy were distributed as follows:

a) Destiny is a written text, something that is prescribed to each person before birth. It is connected with the Holy God, and nobody knows what is written on his forehead, when, where and under what circumstances a person is born and passes away is only known to one creator: huwa ma yaktubaha Allahu lana (something ordered by Allah); maktub (written, ordered, intended by destiny); al-maktub (written, ordered); ma kataba Allahu lana min ma'kulu wa mashrub wa 'umr (something that the God ordered us to eat, drink and live (life)).

b) Destiny is a life fate: huwa an-nasib (destiny); nasib (1. Share, part 2. Fate, destiny); an-nasibu fi-alhayati (life fate); alha dd $\mathrm{u}$ fi ad-dunyayi (share, happiness in life); ma qismatu Allahu lana min ar-rizqi wa al-ma'ishati (fate and livelihood which Allah gave us); huwa nasibu al-fardi (fate, destiny of each person).

c) Destiny is the Allah's will, something predetermined by God: qada wa qadar (destiny and predestination); huwa amru Allahu Subhanahu wa ta'ala (order of Allah); iman (faith in God); nu'minu bima qada'a Allahu wa qadar (we believe in what the Allah prescribed); la mufar minhu (Inevitable!); min muqaddirat al-mawla 'aza wa jalla (something that is predetermined by the Lord).

Death is a religious and philosophical category of life. This component is closely linked to destiny. Death represents reality defining the end of human life and actions of all categories of destiny.

d) Destiny is the end, death: al-mavt (death, demise), al-mawta insha Allah (death, let it be the Allah wil); ma yantaha ilayha al-amri (something that comes to an end by order); an-nihayat (end), muntaha (end).

e) Destiny is the place awaiting in the future (another life): al-janat (paradise), katabtu wa lam afkaru fiha ba'da huma ucnayni, jannatun wa narun, ayuhuma taxtarat (I have written, but I don't think that there are concepts of paradise and hell (fire) and that there will be a choice).

\section{Social and life aspect}

Everyday life of a person, sequence of events, actions in space and time, obtained results of each individual and his way of life constitute fundamental categories of destiny. Time and space are also closely linked to this concept - for some people their homeland is destiny, for 
others - the obtained results in life and something that is expected in the future. This mainly concerns the correlation of destiny and time. It means that the meeting of a person with destiny or event takes place in time and space. The questionnaire showed the following ideas related to social and life aspect (139).

a) Destiny - time, result, place: natijatun (result), alxatimatu (end), mustaqbal (future), al-intiha'i (end, termination), 'aqibatun (outcome, consequence, result), as-Sudan (as-Sudan).

Moral and valuable components perform subjective and evaluation function when reflected in ordinary consciousness of national linguistic worldview. Values of life are specific and hence for every nation and every person there are some national and specific components, which are evaluated differently. Someone's destiny is connected with property, and for others justice is important. Many respondents consider a wedding as their destiny. Happiness was also often mentioned.

b) Destiny represents values of life: mal (property), al-insan (person), Al-adl (truth, justice), min al-taqsim (upon distribution) zuruf ul-hayat (living conditions), azzawaj (marriage, wedding, matrimony), ha dd un (fate, destiny, happiness).

Many reactions indicate the relation of destiny to events taking place in life and filling it with reality, existence. It should be noted that in this respect the destiny is described from both positive and negative perspective since the respondents pointed out accidents, incidents, bad destiny.

c) Destiny - course of life, event having both positive and negative connotation: al-hawadic (event, case), hadic (accident, incident), huwa ma qadara laka min waqa'yi (something that is predestined in reality), asmaru-almasir (dark destiny), al-qadar huwa at-taqdir wa attafakur fi taswiyati al-umur (assessment and solution of problems (affairs)).

\section{Conclusion}

The analysis of the association experiment resulted in the following conclusions:

1. The comparative analysis of obtained data shows that the majority of reactions reflect religious and philosophical aspects (172), while the social and life aspect is on the second place (139).

2. The following units mainly represent the macroconcept destiny in Arabic linguoculture: masir, qada wa qadar, qadar, nasib, qismatun, ha dd un, alha dd u fi ad-dunyayi, al-maktub, natijatun, al-xatimatu, alintiha'i, 'aqibatun.

3. It should also be stated that the majority of respondents associate the concept of destiny with something negative thus referring to the following reactions: al-xatimatu, al-intiha'i, 'aqibatun, (end), almawt (death), asmaru-al-masir (bad (dark) destiny).

4. It should be pointed out that the destiny of each person and the entire nation first of all depends on a political situation within the country, on peace, tranquility and mutual understanding, and hence among single reactions the following were identified: al-Asad (Bashar al-Asad ar-rais as-Suriya) Al-Asad (Bashar alAsad is the president of Syria).
5. Spiritual values constitute the culture of every nation, therefore the respondents highlighted fundamental and axiological dominant ideas related to Islam: huwa ma yaktubaha Allahu lana (something ordered by Allah); al-maktub (written, ordered); ma kataba Allahu lana min ma'kulu wa mashrub wa 'umr (something that the God ordered us to eat, drink and live (life)); an-nasibu fi-al-hayati (life fate); alha dd u fi addunyayi (fate, happiness in life); ma qismatu Allahu lana min ar-rizqi wa al-ma'ishati (fate and livelihood which Allah gave us); huwa amru Allahu Subhanahu wa ta'ala (order of Allah); iman (faith in God); nu'minu bima qada'a Allahu wa qadar (we believe in what the Allah prescribed); min muqaddirat al-mawla 'aza wa jalla (something that is predetermined by the Lord); al-janat (paradise).

6. Universal values - mal (property), al-insan (person), Al-adl (truth, justice), az-zawaj (marriage, wedding, matrimony), al-wazifatu (position, post).

Thus, the macroconcept قدر destiny in Arabic language is bound to culture since this concept includes axiological, valuable and moral components, the highest reference points, as well as standards of behavior and is perceived as the evaluation code in the Arabic linguoculture.

\section{Acknowledgements}

The author expresses gratitude to the Russian-Tajik Slavonic University for financing the research under the University Development Program for 2018.

\section{References}

1. A.F. Losev, Myth dialectic (Moscow, 1930)

2. S.Kh. Lyapin, Conceptology: development of the approach, Concepts. Scientific works of Centroconcept (Arkhangelsk: Pomorsky University Publishing House, 1997)

3. D. Iskandarova, Z. Gulova, M. Davlatmirova, N. Karimova, A. Fomin, Monitoring of Tolerance Associative Field and Forecasting of InterEthnical Interrelations, Problems: Questionnaire Survey in the University Environment of Tajikistan, Mediterranean Journal of Social Sciences, 6 (5, S.4), 35-46 (2015)

4. M.B. Davlatmirova, D.M. Iskandarova, N.I. Karimova, Reflection of national significant elements of a macroconcept DESTINY in Tajik and Pamir linguocultures: questionnaire survey in the university environment of Tajikistan, Aspects of cognitive linguistics, 4, 78-84 (2016)

5. D.M Iskandarova et al.. Study of Tolerance in the Youth Environment of Tajikistan (Linguistic Aspects) (Moscow, 2016)

6. I.E. Anichkov, Idiomatics and semantics, Aspects of linguistics, 5, 140-148 (1992)

7. V.M. Savitsky, O.A Kulayeva, Concept of linguistic continuum (Samara: NTC publishing house, 2004) 
8. Z.D. Popova, I.A. Sternin, Outline of cognitive linguistics (Voronezh, 2001)

9. V.I. Karasik, O.G. Prokhvacheva, Ya.V. Zubkova, E.V. Grabarova, Different mentality (Moscow: Gnozis, 2005)

10. E.I. Grishchuk, Abstract lexicon in linguistic consciousness (pilot study of language consciousness of high school students), extended abstract of dissertation.... (Voronezh, 2002)

11. A.V. Rudakova, Interpretative field 'life', Culture of communication and its formation, 9, 54-56 (2002) 